\title{
Title: Content analysis of informed consent for whole genome sequencing offered by direct-to-consumer genetic testing companies
}

Running title: Informed consent for consumer genome sequencing

Emilia Niemiec ${ }^{1,2,3}$, Pascal Borry ${ }^{4}$, Wim Pinxten ${ }^{5}$, and Heidi Carmen Howard ${ }^{6,5}$

${ }^{1}$ Erasmus Plus Doctoral Programme in Law, Science and Technology, CIRSFID, University of Bologna, Via Galliera 3, 40121 Bologna, Italy, Tel: +39 051 277211, Fax: +39 051 260782

2 Department of Law, University of Turin, Lungo Dora Siena 100 A, 10153 Turin, Italy, Tel: +39 011 6706934, Fax: +39 0116709477

${ }^{3}$ Centre for Ethics and Law in the Life Sciences, Leibniz University Hannover, Am Klagesmarkt 14-17, 30159 Hannover, Germany, Tel: +49 511 762-5222

${ }^{4}$ Centre for Biomedical Ethics and Law, Department of Public Health and Primary Care KU Leuven, Kapucijnenvoer 35 Box 7001, 3000 Leuven, Belgium, Tel: +32 163795 17, Fax: +32 16336952

${ }^{5}$ Faculty of Medicine and Life Science, Hasselt University, Martelarenlaan 42, 3500 Hasselt, Belgium

${ }^{6}$ Centre for Research Ethics and Bioethics, Uppsala University, PO Box 564, SE-751 22 Uppsala, Sweden, Tel: +46 18-471 6170

${ }^{\S}$ Corresponding author: Emilia Niemiec, emilia.niemiec@studio.unibo.it

\section{Conflict of interest}

The authors declare no conflict of interest.

Emilia Niemiec has been supported by Erasmus Mundus Master of Bioethics Fellowship and Erasmus Mundus Joint International Doctoral Programme in Law, Science and Technology Fellowship. Part of this work has been supported by the Swedish Foundation for Humanities and Social Sciences (Riksbankens Jubileumsfond under grant M13-0260:1), the Biobanking and Molecular Resource Infrastructure of Sweden (BBMRI.se), the BBMRI-ERIC, and the CHIP ME COST Action IS1303. Part of this work is also supported by the FWO (Flanders-Québec) project. None of these funding sources have had any involvement in the preparation of this article.

This article has been accepted for publication and undergone full peer review but has not been through the copyediting, typesetting, pagination and proofreading process, which may lead to differences between this version and the Version of Record. Please cite this article as doi: 10.1002/humu.23122.

This article is protected by copyright. All rights reserved. 


\begin{abstract}
Whole exome sequencing and whole genome sequencing have become increasingly available in the research and clinical settings and are now also being offered by direct-to-consumer genetic testing companies. This offer can be perceived as amplifying the already identified concerns regarding adequacy of informed consent for both whole exome/genome sequencing and the direct-to-consumer (DTC) genetic testing context. We performed a qualitative content analysis of websites of four companies offering whole exome/genome sequencing DTC regarding the following elements of informed consent: pre-test counselling, benefits and risks, and incidental findings. The analysis revealed concerns including the potential lack of pre-test counselling in three of the companies studied; missing relevant information in the risks and benefits sections; and potentially misleading information for consumers. Regarding incidental findings, only one company, which provides opportunistic screening, provides basic information about their management. In conclusion, some of the information (and related practices) present on the companies' webpages salient to the consent process are not adequate in reference to recommendations for informed consent for whole genome or exome sequencing in the clinical context. Requisite resources should be allocated to ensure that commercial companies are offering high throughput sequencing under responsible conditions, including an adequate consent process.
\end{abstract}

Key words: whole genome sequencing, whole exome sequencing, direct-to-consumer genetic testing, consumer genomics, informed consent

\title{
Introduction
}

\section{Whole exome and genome sequencing applications}

The relatively recent development of next generation sequencing (NGS) technologies has led to a significant decrease in the cost and time required to perform whole genome sequencing (WGS) and whole exome sequencing (WES) (i.e. the sequencing of only protein coding parts of the genome; for the purpose of this article, in which the high-through-put nature of NGS is most salient, both whole genome and whole exome sequencing may be denoted by 'WGS' or 'whole genome sequencing'). These technologies are more powerful and potentially costeffective than previous sequencing technologies and have brought a shift in testing approach from the traditional way of testing only one or a few specific genes to obtaining the 
sequencing information from hundreds or even all the genetic variants in a genome (Wright et al. 2011).

To date, the use of genomic sequencing approaches has proved to be useful in both the research context and clinical context; for instance, in providing molecular diagnoses for Mendelian disorders (Yang et al. 2013), for disorders with complex phenotypic presentations such as intellectual disabilities, or neurological diseases (de Ligt et al. 2012; Martin et al. 2014), potentially enabling targeted therapeutic strategies in some cases (Salleh et al. 2013). WGS can also be used for disease risk predictions (Heo et al. 2013), preconceptional carrier testing (Chrystoja and Diamandis 2014) and prenatal testing (Carss et al. 2014). In the short to medium-term future, other applications of WGS in health care may materialize, including for newborn screening (Solomon et al. 2012), tissue matching (Wright et al. 2011) or screening of embryos (Harper et al. 2013). Despite these technical possibilities, it is important to note that there are still concerns regarding the accuracy, interpretation of results, costeffectiveness, as well as ethical issues (Dewey et al. 2014).

Given the relative novelty of NGS in the clinic and the resulting uncertainty related to implementation, the ethical concerns are numerous, and include but are not limited to issues related to the informed consent (IC) process, unsolicited findings management, opportunistic screening, secondary use of data, data management and storage, privacy and confidentiality, duty to re-contact patients (once new information arises), responsibility towards and communication with family members. All these outstanding issues currently, challenge the effective and responsible implementation of genome-based approaches in health management (Pinxten and Howard 2014) and need to be addressed. Herein we focus on the informed consent process in the more specific commercial context of direct-to-consumer high 
throughput sequencing, which overlap with many of the concerns related to the clinical context.

\section{Direct-to-consumer genetic testing (DTC GT) companies}

Relatively recently, whole genome sequencing services have also been advertised and offered directly to consumers by some companies. These private, for-profit companies operate outside of the conventional public health care system and advertise genetic tests directly to consumers predominantly via the Internet. However, companies are increasingly requiring consumers to contact a health care professional (HCP) in order to obtain a test and/or the test results (Howard and Borry 2012). This type of genetic test which 'are commissioned by the consumer but where a medical practitioner or health professional is involved in the provision of the service' also fall in the scope of DTC genetic tests according to 'A Common Framework of Principles' on DTC genetic testing issued by the Human Genetics Commission (UK) (Human Genetics Commission 2010).

The phenomenon of DTC GT, even before WGS was being offered in this context, has received a lot of attention regarding ethical issues, such as the questionable scientific validity and utility of the tests on offer (McGuire and Burke 2011), the adequacy of information provision and the informed consent procedure (Howard et al. 2010), the potential need for medical oversight and genetic counselling (Hogarth et al. 2008), the testing of children (Borry et al. 2009), the research activities conducted by DTC GT companies (Howard et al. 2010) and the potential burden on the health care system (McGuire and Burke 2011). The adequacy of legislations concerning the activities of DTC GT companies has also been discussed (Kalokairinou et al. 2014). Considering the vast amount of genomic data obtained in WGS as well as difficulties in being able to properly assess or interpret each variant, one could consider that many, if not all, of the ethical, legal and social implications previously addressed at the DTC GT field are amplified in the context of companies offering WGS directly to consumers. As such, this particular type of DTC GT deserves further attention and study.

\section{Informed consent for WGS}

Informed consent is a key component of any responsible intervention in research involving humans or healthcare provision, including the offer of genetic testing (for health purposes), regardless of whether it is provided via a HCP in the conventional health care system or by a private for-profit company. Informed consent constitutes a voluntary permission given by a competent patient to have the test performed after (s)he has been duly informed about the procedure and purpose of the test, including the results it will generate, as well as the potential risks and benefits. The Additional Protocol to the Convention on Human Rights and Biomedicine concerning Genetic Testing for Health Purposes states that 'A genetic test may only be carried out after the person concerned has given free and informed consent to it'. The document also outlines that the consent should be documented and it may be freely withdrawn at any time (Council of Europe 2008). Furthermore, the European Convention on Human

This article is protected by copyright. All rights reserved. 
Rights and Biomedicine ${ }^{\mathrm{a}}$, specifies in Article 5 that a person consenting to an intervention in the health field 'shall beforehand be given appropriate information as to the purpose and nature of the intervention as well as on its consequences and risks.' (Council of Europe 1997) Moreover, the importance of informed consent has been recognized in the recently accepted version of the Proposal for a Regulation of the European Parliament and of the Council on in vitro diagnostic medical devices ${ }^{\mathrm{b}}$ :

'Member States shall ensure that where a genetic test is used on individuals, in the context of healthcare as defined in Article 3(a) of Directive 2011/24/EU and for the medical purpose of diagnostics, improvement of treatments, predictive or prenatal testing, the individual being tested or, where applicable, his or her legally designated representative is provided with relevant information on the nature, the significance and the implications of the genetic test, as appropriate.' (Article 4a) (Council of the European Union 2016)

In the context of WGS, appropriate provision of information about the testing seems to be a particular challenge considering the complexity of the technology used, the volume of information generated, and the wide-ranging nature of findings. The entire sequence of the genome may provide an unprecedented amount of information of various clinical significance and predictive value, which may change with time (Wright et al. 2011). Furthermore, these results may have profound implications for the (psychological) health (care) and reproductive choices of a patient as well as his or her relatives.

Given these challenges, various authors have proposed models for IC and attempted to determine the necessary elements of an adequate IC process for WGS (ACMG Board of Directors 2013; Ayuso et al. 2013; Bunnik et al. 2013, 2014; Jamal et al. 2013; Henderson et al. 2014). Ayuso et al. (2013) specifically analysed articles from the academic literature and guidelines from 'societies' concerning IC for genetic studies and WGS. The authors found a high level of consistency among the documents reviewed and proposed a minimum list of information that should be addressed in IC for WGS: the scope of the test, a description of the test process, the possible benefits and risks, the availability of alternative tests, the voluntary nature of the test, the possibility of refusal, the future use of the samples and the data, the confidentiality of the outcomes and management of incidental findings

\footnotetext{
${ }^{a}$ The Convention on Human Rights and Biomedicine is only legally binding for those countries who have signed and ratified it (http://www.coe.int/en/web/conventions/full-list//conventions/treaty/164/signatures?p auth=GV537xJS). While, not all countries have done this (e.g. Germany, UK, Belgium, etc.), the Convention nonetheless, remains a very important moral benchmark and/or ethical framework in Biomedicine for all countries.

${ }^{b}$ On 15 June 2016 the European Parliament and the Council of Europe have agreed on the draft of the proposal, which will undergo legal-linguistic review and will be adopted by the European Parliament and the Council of Europe, probably at the end of this year. The rules of the regulation will apply 5 years after its publication (http://ec.europa.eu/growth/toolsdatabases/newsroom/cf/itemdetail.cfm?item_id=8863\&lang=en).
}

This article is protected by copyright. All rights reserved. 
(IF) (Ayuso et al. 2013). Moreover, the authors found that the majority of the documents they studied suggest that IC for whole genome sequencing should be given explicitly (Ayuso et al. 2013) (this is understood as being relevant in a context where WGS is only one of the tests being used for diagnosing a disorder, and so an explicit consent should be obtained specifically for the WGS).

Jamal and co-authors (2013) also developed "core elements" of content and procedures for informed consent, data sharing, and results management for whole exome sequencing; even though conducted in a research context, the former overlap with core elements of informed consent identified by Ayuso et al. for the clinical context (Jamal et al. 2013). Furthermore, Jamal and coauthors used the core elements to evaluate the practices and policies of 6 U.S. CLIA- certified labs offering clinical exome sequencing, including the presence of the suggested elements in informed consent forms and their readability. The analysis revealed that laboratory policies vary widely, indicating that developing standards for best practices among exome sequencing providers may be beneficial.

Similarly, Henderson et al. (2014) (Henderson et al. 2014) have analysed IC forms used in nine NIHfunded studies aiming to develop best practices for clinical applications of WGS. On the basis of the analysis the authors have proposed recommendations, which 'can serve as a checklist to help identify gaps and resolve ambiguities in consent forms for sequencing', and which are related to the issues outlined by Ayuso et al. (2013). For example, Henderson et al. suggest describing the meaning of positive, negative and uncertain results, outlining the role of CLIA (Clinical Laboratory Improvement Amendments) certification, and stating the likelihood of obtaining incidental findings. Furthermore, IC forms for WGS have also been analysed in the context of cancer studies. The examination of these IC forms has revealed the tendency for using samples in other, unspecified types of studies and sharing data with other researchers (Allen and Foulkes 2011).

Furthermore, IC and the provision of information on company websites have been investigated in the context of DTC GT companies revealing the inadequacies of these practices (Howard et al. 2010; Lachance et al. 2010; Singleton et al. 2012). None of the studies, however, specifically addressed IC for WGS in the context of companies advertising or selling WGS directly to consumers. Therefore, herein we present an exploratory qualitative study of the information salient to the IC process, which is provided on websites of companies offering whole genome sequencing in the commercial direct-to-consumer context. In particular, we present information regarding the following elements salient to IC: 1) pre-test counselling, 2) expected benefits and possible risks; and 3) management of incidental findings. The information from company websites is then further contextualized and discussed against the backdrop of guidelines such as those from the Presidential Commission for the Study of Bioethical Issues (PCSBI) (Presidential Commission for the Study of Bioethical Issues 2013), recommendations for IC for WGS by Ayuso and colleagues (Ayuso et al. 2013), and the American College of Medical Genetics (ACMG) recommendations for the reporting of secondary findings (Green et al. 2013).

This article is protected by copyright. All rights reserved. 


\section{Methods}

This study is an explorative qualitative analysis of the informed consent information for whole genome and/or whole exome sequencing offered by DTC companies. We use a broad concept of DTC, including companies that offer genetic testing without a HCP, as well as those that aim marketing directly at consumers, while requiring a physician's request to obtain the test. This approach is congruent with the scope of DTC GT given by the Human Genetics Commission, which included situations where 'tests are commissioned by the consumer but where a medical practitioner or health professional is involved in the provision of the service' (Human Genetics Commission 2010).

The number and content of DTC genetic and genomic testing companies is often changing; this includes information about informed consent ${ }^{\mathrm{c}}$. Against this background, and since no other academic article has addressed the specific issue of consent in the distinct context of WGS/WES, we opted for a non-exhaustive explorative qualitative study of a convenient and varied sample of company websites, which were selected between November 2013 and January 2014. Companies were identified through the academic literature (mostly via articles addressing DTC genetics), as well as with a general Internet search in English using the search engine Google and terms including 'genetic test', 'direct to consumer', 'whole genome sequencing' and 'whole exome sequencing'.

Our qualitative analysis is focused on the website sections and documents available online that are presented by the companies with which consumers should agree and/or sign in order to undertake the test. Specifically, these are the IC documents, statement of consent, terms of service, terms and conditions, disclaimer and privacy policy (Table 1).

For the qualitative content analysis of the relevant documents on the websites, we build on the study of Ayuso et al. (2013) and used the following elements of IC as the major codes: 1) pre-test counselling, 2) expected benefits and possible risks; and 3) management of incidental findings. These were underlined as being particularly important and relevant for IC in the context of WGS (Ayuso et al. 2013). The website documents were accessed in October 2014. The documents were perused for all material relevant to the codes above and were organized under these headings initially by one author; these initial results were reviewed by a second author and disagreements were resolved until both agreed on the adequate organization. Final tables including representative quotes were reviewed by all three authors.

\footnotetext{
'Indeed, some companies' policies have already changed since our study, and as mentioned in the discussion, it is relevant that future studies return to these companies as well as include novel companies not addressed herein. For example, the version of Illumina's consent form analysed herein is not available online any more. For a copy of the form please contact the corresponding author.
}

This article is protected by copyright. All rights reserved. 


\section{Results}

\section{The DTC WGS companies identified and the studied website documents}

Four companies, Illumina, Gentle, Gene by Gene and Inneova, were identified for this study. They offer WES and/or WGS as well as provide different types/scope of data/results and analysis (e.g. carrier status, pharmacogenomics). The basic description and information regarding these four companies are outlined in Table 1.

All the companies studied advertise their services directly to consumers on the Internet. However, some websites also contain sections dedicated to physicians, who are required to order the test, except for the company Gene By Gene's offer of research and consumer testing, for which the company does not require a HCP.

All companies' websites analysed provide at least one document and/or a section on the webpage that needs to be agreed to or signed in order to undertake the test (Table 1). Three companies have documents on their website with 'consent' in the title; meanwhile, Gene By Gene only has a 'Terms and Conditions' section of the website and specifies that in case of 'Clinical Genetic Testing' the physician has to obtain IC from the consumer; however it does not state whether this includes a physical document that must be signed by the consumer: 'Prior to placing an order, the ordering physician or genetic counselor is responsible for obtaining the informed consent from the patient whose sample is being sent for testing (...)' (https://www.genebygene.com/pages/terms). Such a statement is not included in the section for 'Research and Consumer testing' in 'Terms and Conditions' of Gene by Gene (https://www.genebygene.com/pages/terms).

The results of the content analysis regarding the following elements of IC: pre-test counselling, benefits and risks as well as incidental findings are presented below and shown in tables 2-4.

\section{Pre-test counselling}

Only Illumina (seemingly) requires pre-test counselling as a condition for undertaking the test. In the IC form a consumer has to sign the following statements:

'I have been offered the opportunity to ask questions and discuss with my healthcare provider the benefits and limitations of the test to be performed as indicated on the associated test request form. I have discussed with the medical practitioner ordering this test the reliability of positive or negative test results and the level of certainty that a positive test result for a given disease or condition serves as a predictor of that disease or condition.'

This article is protected by copyright. All rights reserved. 
(http://res.illumina.com/documents/clinical/forms/form-test-req-undiagnosed-disease.pdf) d

Another company, Gentle, vaguely suggests some form of pre-test counselling to consumers in its IC section of the webpage: 'If you still have unanswered questions, be sure to ask us or your physician before you agree to take the DNA test being offered by us.' (https://www.gentlelabs.com/consent?content_only=true). No information about pre-test counselling was found on the studied websites' sections of Gene by Gene and Inneova.

\section{Benefits and risks}

In the studied sections of the websites, all the companies provide general information about benefits and risks; however specific sections labelled 'Benefits' and 'Risks' are explicitly distinguished only in the IC document of Illumina and Gentle. More specific subthemes were identified within the subject Benefits and Risks (Table 3, in bold in columns 2 and 3); these were used to classify the benefits and risks and the labels were derived and modified from the classification outlined by Ayuso et al., 2013 (Ayuso et al. 2013).

Three companies outline that the results may indicate disease risks and predispositions (Table 3 ). Moreover, Illumina and Gentle state that test results may help to make more informed healthcare choices; Gentle adds that the knowledge from the testing may empower persons to make 'important life planning decisions'. Furthermore, Gentle outlines as a benefit, gaining knowledge about one's carrier status, the possibility of adjusting drug therapy based on the genetic results, and gaining insight into one's ancestry. This company also mentions as a benefit the possibility of participating in research studies conducted by the company.

All the companies provide, at least, a general and/or short description of risks related to undertaking WGS (Table 3). The types of risks and concerns mentioned include the following: medical and physical risks, psychological risks, discrimination risks, and implications for family members. Implications for reproductive choices are mentioned only by one company, Inneova: 'I realize the possible far-reaching implications of the information obtained through predictive genetics testing in affecting my life choices as well as those of my relatives, children, and unborn children' (http://www.inneova.com/contenu.php?page=terms.php).

\section{Incidental findings and categorization of genetic information}

Only one of the analysed companies, Illumina, directly addresses the issue of incidental findings (IF) in its IC form (Table 4). The company refers to the first version of the American College of Medical Genetics' (ACMG) recommendations for reporting of incidental findings (2013) (Green et al. 2013) and together with the results of Undiagnosed Disease Test provides an incidental findings report that may contain information on some of 57 variants unrelated to the indication for testing.

\footnotetext{
${ }^{d}$ At the time of submitting the article the link to this document was no longer functional. For a copy of the form please contact the corresponding author.
}

This article is protected by copyright. All rights reserved. 
Meanwhile, in the consent form for Illumina's Predisposition Screen test the possible findings are categorized (into: childhood onset and adult onset; subcategories: medically actionable, not medically actionable, cancer, neurologic conditions) and the consumer has the possibility to opt out of some of them. Although Gentle does not mention IF, the company does emphasize that customers can choose to exclude any condition from the analysis: 'It is important to mention that you can choose to exclude any of the tests from the results before submitting your sample.'

\section{Discussion}

\section{Informed consent in the context of DTC WGS companies}

The content analysis of DTC companies described herein has been conducted using some of the elements of IC for WGS in the clinical setting recommended by Ayuso et al. (2013) (Ayuso et al. 2013). It should be noted that there are significant differences between the offers of WGS in a 'traditional' clinical genetics context versus the commercial DTC setting, even if the latter involves a healthcare professional. As explained in the recent guideline issued by the Presidential Commission for the Study of Bioethical Issues (PCSBI): 'Clinicians owe stringent fiduciary duties to patients, which entail an obligation to act in furtherance of the patient's best interests. Non-clinician DTC providers have less stringent duties, including duties that might be limited or circumscribed by contract. Consumers should be made aware of these distinctions prior to consenting to undergo DTC testing.' (p.103-104) (Presidential Commission for the Study of Bioethical Issues 2013). Indeed, in the context of DTC companies the contract describing the conditions of the service is usually stated in terms of service to which a consumer has to agree prior to buying the test. However, if the purpose of the test is health-related, signing a contract cannot fully replace the function of IC, which aims, among others, to provide understandable and balanced information about the test (Bunnik et al. 2014). The tests included in this study are advertised as having (to some extent) a health-related purpose or as clinical tests, therefore, the presence of adequate IC in the studied DTC companies appears to be advisable.

\section{Explicit informed consent and pre-test counselling}

Explicit informed consent, which is recommended by Ayuso et al. (2013) for clinical WGS, may be defined as one for which 'Those who request consent must provide an explicit statement of the nature and purposes of a proposed course of action, its effects, risks and other features, to those whose consent is sought. Those who are asked to consent must show explicitly that they understand this information and agree to the proposal' (Manson and O'Neill 2007). The process of explicit IC typically involves documents, signatures and formal statements (Manson and O'Neill 2007). Therefore, in this study we have focused on the documents or the section of the websites which the consumers have to agree to in order to be tested. However, in order to be genuinely informed consent should not be reduced to signing a document but rather through dialogue with a qualified HCP it should be ensured that the patient truly understands the information provided and is competent to make a choice (European Society of Human Genetics 2010).

This article is protected by copyright. All rights reserved. 
Although all four companies provide some form of document addressing consent, only Illumina requires pre-test counselling understood as face-to-face consultation with a physician. In the other companies studied, most of the tests have to be ordered by the physician meaning that the consumer has to contact one in order to be tested. This, however, does not guarantee that adequate counselling takes place, given the concerns about the expertise in genetics and impartiality of the health care professionals (Howard and Borry 2012). Indeed, including a third party HCP in the process raises the question of who bears the (fundamental) ethical and legal responsibility for taking adequate consent? Of course, the HCP must adhere to the general medical code of conduct, but depending on her/his specialty, is (s)he aware of the specific guidelines for genetic testing?

Another important result that brings attention to the involvement of healthcare professionals in testing is a lack of involvement of a physician in undertaking the consumer test in Gene By Gene company. Although 'Terms and Conditions' state that the services listed in 'Research and Consumer Testing' section 'are not to be used to diagnose, prevent, or treat any condition or disease or to ascertain the state of health for any individual' (https://www.genebygene.com/pages/terms), the description of the test suggests that it may provide health-related information: 'Sequencing of the exome can help identify variants that may be the genetic cause of a wide range of traits and conditions.' (https://www.genebygene.com/pages/research\#). Therefore, the involvement of a genetics professional seems to also be advisable in the case of 'Research and Consumer Testing' of Gene By Gene, which could prevent misinterpretation of the results or unnecessary follow-up care.

In addition, although the non-clinician DTC provider may have less stringent duties as stated by the PCSBI (Presidential Commission for the Study of Bioethical Issues 2013), the full role of a clinician in the DTC context still remains blurry. It is unknown to what extent physicians in the DTC context follow the same protocol as geneticist follow in the traditional health care system.

Another aspect related to informed consent is the potentially low readership of the consent documents analysed herein. It has already been shown that most of the consumers read very little of the terms of service agreements (e.g. when purchasing software (Maronick 2014) or accessing WiFi). This may suggest that although the documents have the word 'consent' in the title and/or are aimed to be read and agreed to, the consumers are not acquainted with their content. This issue requires further analysis to assess the accessibility and readability of such documents.

\section{Information about benefits and risks}

The content analysis of the sections of companies' websites reveals that the information regarding possible risks and benefits is scarce, general and omits some relevant elements such as description of the implications for the reproductive choices, which has been suggested by the recommendations for IC for WGS by Ayuso and colleagues (Ayuso et al. 2013). Furthermore, some of the outlined information about benefits may be misleading such as regarding the possibility to participate in research studies (Table 3), which, in fact, does not necessarily benefit participants per se and is associated with various risks. Similarly, knowing the information about the carrier status is mentioned as a benefit in Gentle's IC website section, but the implications for reproductive choices of having this knowledge are not described (Table 3). What is more, the information provided in the

This article is protected by copyright. All rights reserved. 
documents that need to be signed differs from the information placed in other sections of the website, which seem to be more encouraging about the possible results. For example, in the "Why do a genetic test?' section of the Inneova website they state that:

'The objective of predictive genetics testing from Inneova ${ }^{T M}$ is to determine each person's specific genetic features - and notably vulnerabilities - in order to allow highly-qualified practitioners in anti-aging and preventive medicine identify appropriate measures designed to counter-balance weaknesses and maintain good health, as well as help prevent the development of specific diseases or at least to delay their onset' (http://www.inneova.com/tout.php?page=prev_why.php\&menu=2).

This may be misleading as consumers may not read the sections 'Terms of Service' or 'Terms and Conditions' (Howard et al. 2010), but rather take the decisions based on the information available on the main webpages. Finally, the content of the risks' sections in the documents of Inneova and Gene By Gene could suggest that they were designed or written more in a way to protect the company from any liability rather than to explain and inform about potential disadvantages, e.g. 'I agree that ICL (...) assumes no liability for any stress, strain, hardship, adverse medical condition, financial loss, or other circumstances that I may suffer as a result of the receipt or reference to any predictive genetics test results and/or interpretations thereof supplied to me by ICL' (http://www.inneova.com/contenu.php?page=terms.php).

Some of the findings presented herein are in line with the results of the study of Singleton et al, 2012 on informed choice in DTC-GT companies, which focuses on the websites of the DTC GT companies containing consumer-focused content excluding terms and conditions and privacy statements, therefore being to some extent complementary to this study. Singleton et al. found that the amount of information describing benefits outweighed risks statements and that the websites present conflicting information stating that the tests can help to prevent diseases, simultaneously giving information that the test cannot be used for diagnosis or treatment (Singleton et al. 2012). Similarly, Skirton et. al have found that misleading, conflicting or incomplete information was present on the websites of DTC companies offering non-invasive prenatal testing (Skirton et al. 2015).

\section{Incidental/secondary findings}

The last, but not the least element of IC analysed in this study is the management of incidental findings. The term 'incidental findings' refers to 'results that are outside the original purpose for which a test or procedure was conducted' (Presidential Commission for the Study of Bioethical Issues 2013), while secondary findings are results being sought deliberately because of the recommendations of an expert body as it has been defined by the PCSBI in the report on incidental and secondary findings (Presidential Commission for the Study of Bioethical Issues 2013). The issue of incidental and secondary findings appears particularly relevant in the context of WGS generating vast amount of data for analysis (Burke et al. 2013). Therefore, this topic has been discussed at great length and various expert societies have addressed it in recommendations. The PCSBI emphasizes the role of IC, and for the particular context of DTC companies suggests that the providers should

This article is protected by copyright. All rights reserved. 
develop adequate procedures to manage IF and provide consumers with understandable materials explaining these procedures (Presidential Commission for Study of Bioethical Issues 2014). The American College of Medical Genetics (ACMG) also has issued recommendations for the reporting of secondary findings (although they use the term incidental findings, this is misleading since what they describe is opportunistic screening and not the strictly 'unsolicited' findings as described above) in WGS (Green et al. 2013). This policy statement of the ACMG suggests that secondary findings concerning 24 indicated conditions (related to 56 gene variants affecting function) should be sought and reported, however the patient may refuse the analysis of some of these genes if they are unrelated to the indication for testing, which should be done during the process of IC (Green et al. 2013; ACMG Board of Directors 2014). In contrast, the recommendations of the European Society of Human Genetic which address incidental findings do not provide a specific list of reportable conditions but rather suggest narrowing the scope of the sequence analysis and developing guidelines and protocols (van El et al. 2013) in order to reduce the chances of encountering IF all together. Finally, some authors propose models of stratification of information derived from WGS including incidental/secondary findings which will help the discussion with, and the decision-making by the patient (Berg et al. 2011; Ayuso et al. 2013).

Only one company out of the four studied addresses the issue of incidental/secondary findings and provides a report on IF complying with the recommendations of ACMG (Green et al. 2013) (hence also conducting opportunistic screening). However, the company does not indicate in the informed consent form whether the consumer has an opportunity to opt out of the analysis of some of the genes listed by the ACMG. Furthermore, regarding the primer issued by the PCSBI on IF (Presidential Commission for the Study of Bioethical Issues 2013) for DTC as well as the recent update of the recommendations for reporting secondary findings in genome-scale sequencing (ACMG Board of Directors 2014) the term 'incidental findings' used by Illumina is not consistent with the definition suggested by the PCSBI and should be replaced by the term 'secondary findings' in order to comply with the guidelines mentioned. Nevertheless, in the IC for Undiagnosed Disease Test Illumina seems to implement the recommendation included in the mentioned document for DTC providers, which are to prepare a plan for the management of incidental and secondary findings and to provide easily accessible information for consumers about this procedure.

The IC form for Illumina's Predisposition Screen test introduces categories of genetic information, which consumer may choose not to receive exercising his/her 'right not to know' some of the medical information. The categories of genetic information introduced by Illumina are to some extent in line to some to those suggested by Ayuso et al. (2013) as they arrange the conditions according to the time of onset and medical actionability facilitating the choice of consumers (Ayuso et al. 2013).

\section{Conclusions}

Concerning the elements studied herein the consent forms and documents on companies' websites do not appear to fulfil the requirements for genuinely explicit and informed consent for WGS in the clinic as suggested by Ayuso et al. (2013). This highlights the present need to develop and implement

This article is protected by copyright. All rights reserved. 
'best practices' for the DTC GT context with regard to IC and the provision of information about testing being offered. Moreover, the specific context of the commercial DTC GT companies which involve healthcare professionals could benefit from developing guidelines that specifically address this practice.

This explorative qualitative study has some limitations. Since it considers a small and convenient sample of DTC WGS/WES companies' and a subset of their written policies, it does not provide an exhaustive overview of all companies, their practices and associated ethical issues involved in the consent process. Indeed, we stress that the goal of this article is not meant to be an exhaustive, or generalizable (in a quantitative statistical way) analysis of DTC WGS companies, but rather a qualitative exploration of the activities that exist with respect to consent. Moreover, information provided on other pages of companies' websites not analysed herein may also be relevant to IC process, which requires further investigation. Furthermore, other information such as that related to storage and future use of consumers' samples and data pertain to IC and their presence in the process of IC in DTC companies also needs to be discussed. Finally, it is important to note that the nature of the DTC genetic and genomic testing market is very dynamic and the practices of companies are continuously evolving, thus it is important to monitor and continue to study and reflect on these activities.

In conclusion, we acknowledge that informed consent is just one of the elements related to the ethical issues around WGS. Its adequacy may not resolve the other ethical issues related to the companies that offer WGS, however, as stakeholders in genetics, we should expect and aim to support and provide an adequately informed consent process in order to respect individuals in their health-related decisions..

\section{Acknowledgements}

Emilia Niemiec has been supported by Erasmus Mundus Master of Bioethics Fellowship and Erasmus Mundus Joint International Doctoral Programme in Law, Science and Technology Fellowship. Part of this work has been supported by the Swedish Foundation for Humanities and Social Sciences (Riksbankens Jubileumsfond under grant M13-0260:1), the Biobanking and Molecular Resource Infrastructure of Sweden (BBMRI.se), the BBMRI-ERIC, and the CHIP ME COST Action IS1303. Part of this work is also supported by the FWO (Flanders-Québec) project. None of these funding sources have had any involvement in the preparation of this article.

We thank Prof. Michele Graziadei for his insightful comments and Dr Patrick Miqueu for his overall assistance during the work on this project.

\section{Conflict of Interest Statement}

The authors declare no conflict of interest.

This article is protected by copyright. All rights reserved. 


\section{References}

ACMG Board of Directors. 2013. Points to consider for informed consent for genome/exome sequencing. Genet Med 15:748-749.

ACMG Board of Directors. 2014. ACMG policy statement: updated recommendations regarding analysis and reporting of secondary findings in clinical genome-scale sequencing. Genet Med 17:6869.

Allen C, Foulkes WD. 2011. Qualitative thematic analysis of consent forms used in cancer genome sequencing. BMC Med Ethics 12:14.

Ayuso C, Millán JM, Mancheño M, Dal-Ré R. 2013. Informed consent for whole-genome sequencing studies in the clinical setting. Proposed recommendations on essential content and process. Eur J Hum Genet 21:1054-1059.

Berg JS, Khoury MJ, Evans JP. 2011. Deploying whole genome sequencing in clinical practice and public health: meeting the challenge one bin at a time. Genet Med 13:499-504.

Borry P, Howard HC, Sénécal K, Avard D. 2009. Direct-to-consumer genome scanning services. Also for children? Nat Rev Genet 10:8.

Bunnik EM, Janssens a CJW, Schermer MHN. 2013. A tiered-layered-staged model for informed consent in personal genome testing. Eur J Hum Genet 21:596-601.

Bunnik EM, Janssens a CJW, Schermer MHN. 2014. Informed consent in direct-to-consumer personal genome testing: the outline of a model between specific and generic consent. Bioethics 28:343-351.

Burke W, Trinidad SB, Clayton EW. 2013. Seeking genomic knowledge: the case for clinical restraint. Hastings Law J 64:1649-1664.

Carss KJ, Hillman SC, Parthiban V, McMullan DJ, Maher ER, Kilby MD, Hurles ME. 2014. Exome sequencing improves genetic diagnosis of structural fetal abnormalities revealed by ultrasound. Hum Mol Genet 23:3269-3277.

Chrystoja CC, Diamandis EP. 2014. Whole genome sequencing as a diagnostic test: challenges and opportunities. Clin Chem 60:724-733.

Council of Europe. 1997. Convention for the Protection of Human Rights and Dignity of the Human Being with Regard to the Application of Biology and Medicine: Convention on Human Rights and Biomedicine.

Council of Europe. 2008. Additional Protocol to the Convention on Human Rights and Biomedicine Concerning Genetic Testing for Health Purposes.

Council of the European Union. 2016. Proposal for a Regulation of the European Parliament and of the Council on in Vitro Diagnostic Medical Devices.

Dewey FE, Grove ME, Pan C, Goldstein BA, Bernstein JA, Chaib H, Merker JD, Goldfeder RL, Enns GM,

This article is protected by copyright. All rights reserved. 
David SP, Pakdaman N, Ormond KE, et al. 2014. Clinical Interpretation and Implications of WholeGenome Sequencing. Jama 311:1035.

El CG van, Cornel MC, Borry P, Hastings RJ, Fellmann F, Hodgson S V, Howard HC, Cambon-Thomsen A, Knoppers BM, Meijers-Heijboer H, Scheffer H, Tranebjaerg L, et al. 2013. Whole-genome sequencing in health care: recommendations of the European Society of Human Genetics. Eur J Hum Genet 21:580-584.

European Society of Human Genetics. 2010. Statement of the ESHG on direct-to-consumer genetic testing for health-related purposes. Eur J Hum Genet 18:1271-1273.

Green RC, Berg JS, Grody WW, Kalia SS, Korf BR, Martin CL, McGuire AL, Nussbaum RL, O'Daniel JM, Ormond KE, Rehm HL, Watson MS, et al. 2013. ACMG recommendations for reporting of incidental findings in clinical exome and genome sequencing. Genet Med 15:565-574.

Harper JC, Geraedts J, Borry P, Cornel MC, Dondorp W, Gianaroli L, Harton G, Milachich T, Kääriäinen $\mathrm{H}$, Liebaers I, Morris M, Sequeiros J, et al. 2013. Current issues in medically assisted reproduction and genetics in Europe: research, clinical practice, ethics, legal issues and policy. Eur J Hum Genet 21 Suppl 2:S1-S21.

Henderson G, Wolf S, Kuczynski K, Joffe S, Sharp R, Parsons D, Knoppers B, Yu J-H, Appelbaum PS. 2014. The challenge of informed consent and return of results in translational genomics: empirical analysis and recommendations. J Law, Med Ethics 42:344-355.

Heo SG, Hong EP, Park JW. 2013. Genetic Risk Prediction for Normal-Karyotype Acute Myeloid Leukemia Using Whole-Exome Sequencing. Genomics and Informatics 11:46-51.

Hogarth S, Javitt G, Melzer D. 2008. The current landscape for direct-to-consumer genetic testing: legal, ethical, and policy issues. Annu Rev Genomics Hum Genet 9:161-182.

Howard HC, Borry P. 2012. Is there a doctor in the house?: The presence of physicians in the directto-consumer genetic testing context. J Community Genet 3:105-112.

Howard HC, Knoppers BM, Borry P. 2010. Blurring lines. The research activities of direct-to-consumer genetic testing companies raise questions about consumers as research subjects. EMBO Rep 11:579582.

Human Genetics Commission. 2010. A Common Framework of Principles for Direct-to-Consumer Genetic Testing Services.

Jamal SM, Yu J, Chong JX, Dent KM, Conta JH, Tabor HK, Bamshad MJ. 2013. Practices and Policies of Clinical Exome Sequencing Providers : Analysis and Implications. Am J Med Genet 935-950.

Kalokairinou L, Howard HC, Borry P. 2014. Direct-to-Consumer Genetic Testing. eLS, Chichester: John Wiley \& Sons, Ltd,.

Lachance CR, Erby LAH, Ford BM, Allen VC, Kaphingst KA. 2010. Informational content, literacy demands, and usability of websites offering health-related genetic tests directly to consumers. Genet Med 12:304-12.

This article is protected by copyright. All rights reserved. 
Ligt J de, Willemsen MH, Bon BWM van, Kleefstra T, Yntema HG, Kroes T, Vulto-van Silfhout AT, Koolen D a, Vries P de, Gilissen C, Rosario M del, Hoischen A, et al. 2012. Diagnostic exome sequencing in persons with severe intellectual disability. N Engl J Med 367:1921-1929.

Manson NC, O'Neill O. 2007. Rethinking Informed Consent In Bioethics. Cambridge: Cambridge University Press.

Maronick TJ. 2014. Do Consumers Read Terms of Service Agreements When Installing Software ? A Two-Study Empirical Analysis. Int J Bus Soc Res 4:137-145.

Martin HC, Kim GE, Pagnamenta AT, Murakami Y, Carvill GL, Meyer E, Copley RR, Rimmer A, Barcia G, Fleming MR, Kronengold J, Brown MR, et al. 2014. Clinical whole-genome sequencing in severe earlyonset epilepsy reveals new genes and improves molecular diagnosis. Hum Mol Genet 23:3200-3211.

McGuire AL, Burke W. 2011. Health system implications of direct-to-consumer personal genome testing. Public Health Genomics 14:53-58.

Pinxten W, Howard HC. 2014. Ethical issues raised by whole genome sequencing. Best Pract Res Clin Gastroenterol 28:269-279.

Presidential Commission for Study of Bioethical Issues. 2014. Direct-to-Consumer Provider Primer: Incidental and Secondary Findings.

Presidential Commission for the Study of Bioethical Issues. 2013. Anticipate and Communicate: Ethical Management of Incidental and Secondary Findings in the Clinical, Research, and Direct-toConsumer Contexts.

Salleh MZ, Teh LK, Lee LS, Ismet RI, Patowary A, Joshi K, Pasha A, Ahmed AZ, Janor RM, Hamzah AS, Adam A, Yusoff $K$, et al. 2013. Systematic pharmacogenomics analysis of a Malay whole genome: proof of concept for personalized medicine. PLoS One 8:e71554.

Singleton A, Erby LH, Foisie K V, Kaphingst KA. 2012. Informed choice in direct-to-consumer genetic testing (DTCGT) websites: a content analysis of benefits, risks, and limitations. J Genet Couns 21:433-439.

Skirton H, Goldsmith L, Jackson L, Lewis C, Chitty LS. 2015. Non-invasive prenatal testing for aneuploidy: A systematic review of Internet advertising to potential users by commercial companies and private health providers. Prenat Diagn.

Solomon BD, Pineda-Alvarez DE, Bear KA, Mullikin JC, Evans JP. 2012. Applying Genomic Analysis to Newborn Screening. Mol Syndromol 3:59-67.

Wright C, Burton H, Hall A, Moorthie S, Pokorska-Bocci A, Sagoo G, Sanderson S, Skinner R. 2011. Next Steps in the Sequence. The Implications of Whole Genome Sequencing for Health in the UK. Cambridge, UK: PHG Foundation.

Yang Y, Muzny DM, Reid JG, Bainbridge MN, Willis A, Ward P a, Braxton A, Beuten J, Xia F, Niu Z, Hardison M, Person R, et al. 2013. Clinical whole-exome sequencing for the diagnosis of mendelian disorders. N Engl J Med 369:1502-1511.

This article is protected by copyright. All rights reserved. 


\section{Web references}

Gene By Gene. Research and Consumer Genetics. Whole Exome Sequencing: https://www.genebygene.com/pages/research\# (accessed 17 January 2015).

Gene By Gene. Terms and Conditions: https://www.genebygene.com/pages/terms (accessed 17 January 2015).

Gentle. Informed Consent: https://www.gentlelabs.com/consent?content_only=true (accessed 2 February 2014).

Illumina. Informed consent: http://res.illumina.com/documents/clinical/forms/form-test-requndiagnosed-disease.pdf (accessed 25 October 2014).

Inneova. Statement of consent: http://www.inneova.com/contenu.php?page=terms.php (accessed 25 October 2014).

Inneova. Why do a genetic test: http://www.inneova.com/tout.php?page=prev_why.php\&menu=2 (accessed 15 July 2015).

This article is protected by copyright. All rights reserved. 
Table 1 Basic information about the four companies selling WGS included in this study. The websites were accessed on 23 October 2014. HCP = healthcare professional.

\begin{tabular}{|c|c|c|c|c|}
\hline $\begin{array}{l}\text { Company name, } \\
\text { country and website } \\
\text { address }\end{array}$ & \multicolumn{2}{|c|}{ Description of service } & $\begin{array}{c}\text { Who can } \\
\text { order the } \\
\text { test }^{\text {a }}\end{array}$ & $\begin{array}{l}\text { Sections of the } \\
\text { websites studied }\end{array}$ \\
\hline $\begin{array}{c}\text { Illumina, USA } \\
\text { http://www.illumina.com/ } \\
\text { clinical/illumina_clinical_la } \\
\text { boratory.html }\end{array}$ & \multicolumn{2}{|c|}{$\begin{array}{l}\text { WGS: } \\
\text { TruGenome Undiagnosed Disease Test - with analysis and } \\
\text { interpretation based on clinical indication; } \\
\text { TruGenome Predisposition Screen - with analysis and interpretation } \\
\text { of } 1,600 \text { genes that have established associations to a set of } \\
\text { conditions or diseases caused by single genes } \\
\text { TruGenome Technical Sequence Data - raw data without interpretation }\end{array}$} & only HCP & $\begin{array}{l}\text { Informed Consent } \\
\text { (different form for } \\
\text { each test) }\end{array}$ \\
\hline $\begin{array}{l}\text { Gentle, Belgium } \\
\text { https://gentlelabs.com/ }\end{array}$ & \multicolumn{2}{|c|}{$\begin{array}{l}\text { WES - with analysis and interpretation of genetic variants related to } \\
\text { carrier status, health risks and response to medications (please note } \\
\text { that since this analysis, Gentle no longer offers DTC genetic testing }{ }^{b} \text { ) }\end{array}$} & only HCP & $\begin{array}{l}\text { Informed } \\
\text { Consent, } \\
\text { Terms of } \\
\text { Service }\end{array}$ \\
\hline \multirow[t]{2}{*}{$\begin{array}{l}\text { Gene By Gene, USA } \\
\text { https://www.genebygene. } \\
\text { com/\# }\end{array}$} & Clinical testing & $\begin{array}{l}\text { WES - with analysis, search for the variant(s) of } \\
\text { potential causative effect for the described } \\
\text { phenotype }\end{array}$ & only HCP & \multirow[t]{2}{*}{$\begin{array}{l}\text { Terms and } \\
\text { Conditions }\end{array}$} \\
\hline & $\begin{array}{l}\text { Research and } \\
\text { consumer testing }\end{array}$ & WES and WGS - raw data or with analysis & $\begin{array}{l}\mathrm{HCP} \text { and } \\
\text { non-HCP }\end{array}$ & \\
\hline $\begin{array}{c}\text { Inneova, Canada } \\
\text { http://www.inneova.com/ }\end{array}$ & \multicolumn{2}{|c|}{$\begin{array}{l}\text { WGS - with analysis and interpretation concerning interaction of genes } \\
\text { with ageing, nutritional and lifestyle choices and diseases }\end{array}$} & only HCP & $\begin{array}{l}\text { Statement of } \\
\text { consent, } \\
\text { Disclaimer and } \\
\text { privacy policy }\end{array}$ \\
\hline
\end{tabular}

a According to 'A common framework of principles for DTC GT services' issued by the Human Genetics Commission (UK) ${ }^{14}$ the type of genetic tests which 'are commissioned by the consumer but where a medical practitioner or health professional is involved in the provision of the service' also fall in the scope of DTC genetic tests.

"At the time of submitting this article Gentle stated on its company website "In order to focus all our efforts on the clinical diagnostics market, we are no longer-selling the Gentle test to end users. If you are interested in our clinical interpretation services, please contact us." (https://store.gentlelabs.com/)

This article is protected by copyright. All rights reserved. 
Table 2 Information about the pre-test counselling for WGS offered by the studied companies. The information was accessed on 25 October 2014.

\begin{tabular}{|c|c|c|}
\hline \multicolumn{2}{|c|}{$\begin{array}{c}\text { Company name/type of } \\
\text { service }\end{array}$} & Pre-test counselling \\
\hline \multicolumn{2}{|c|}{ Illumina } & $\begin{array}{r}\text { Not provided by the company but } \\
\text { required for IC }\end{array}$ \\
\hline \multirow{2}{*}{ Gentle } & $\begin{array}{r}\text { Not provided by the company but } \\
\text { recommended in IC }\end{array}$ \\
$\begin{array}{c}\text { Gene By } \\
\text { Gene }\end{array}$ & Clinical testing & Nosearch and \\
\cline { 2 - 2 } & consumer testing & \\
\hline \multicolumn{2}{|c|}{ Inneova } & No information \\
\hline
\end{tabular}

This article is protected by copyright. All rights reserved. 
Table 3 Information about the possible benefits and risks of WGS included in the studied sections of the companies' websites. Words in bold in 'Benefits' and 'Risks' columns are identified subthemes. The websites were accessed on 25 October 2014.

\begin{tabular}{|c|c|c|}
\hline Company & Benefits & Risks \\
\hline Illumina & $\begin{array}{c}\text { 'Your test results may help you and } \\
\text { your physician make more informed } \\
\text { choices about your healthcare. It is also } \\
\text { possible that your test results will not } \\
\text { provide any benefit.' }\end{array}$ & $\begin{array}{l}\text { Medical and/or physical risks: 'Side effects of } \\
\text { having blood drawn are uncommon, but may } \\
\text { include dizziness, fainting, soreness, bleeding, } \\
\text { bruising, and, rarely, infection.' Psychological: } \\
\text { 'Your test results may reveal information about } \\
\text { yourself, or your relatives, that you would } \\
\text { rather not know. For example, you may learn } \\
\text { information about genetic risks/predispositions } \\
\text { to disease, including ones that might not be } \\
\text { curable; ancestry; etc.' Implications for family } \\
\text { members: 'In a trio or parent/child analysis, it } \\
\text { may be uncovered that a family member is } \\
\text { unrelated to the patient, such as in the case of } \\
\text { adoption or non-paternity. It may not be } \\
\text { possible to prevent learning such information } \\
\text { through this test.' Discrimination risks: } \\
\text { 'Genetic information could be used as a basis of } \\
\text { discrimination. (...) The laws may not protect } \\
\text { against genetic discrimination in other } \\
\text { circumstances such as when applying for life } \\
\text { insurance or long-term disability insurance.' }\end{array}$ \\
\hline Company & Benefits & Risks \\
\hline
\end{tabular}

This article is protected by copyright. All rights reserved. 


\begin{tabular}{|c|c|c|}
\hline Gentle & $\begin{array}{l}\text { Knowledge about disease risks and } \\
\text { predispositions: 'A person found to } \\
\text { have an increased risk of disease might } \\
\text { want to choose preventive or } \\
\text { therapeutic medical treatments. } \\
\text { Having this knowledge can empower a } \\
\text { person and family members to make } \\
\text { important life planning decisions, even } \\
\text { if a cure is not available at the time of } \\
\text { testing. (...) Knowing the genetic } \\
\text { predisposition to these conditions } \\
\text { allows you to take action, even before } \\
\text { symptoms occur.' Information about } \\
\text { carrier status: 'DNA-testing can inform } \\
\text { a person about his/her carrier status } \\
\text { for thousands of genetic conditions. } \\
\text { Many genetic conditions are inherited } \\
\text { in a recessive way. Being a carrier will } \\
\text { usually not affect the health of the } \\
\text { person him/herself, but might affect } \\
\text { the health of future children. Screening } \\
\text { your carrier status for diseases allows } \\
\text { to check whether you might pass on } \\
\text { severe conditions to your children.' } \\
\text { More tailored drug therapy: 'Another } \\
\text { benefit of DNA-testing is that you and } \\
\text { your physician can make informed } \\
\text { decisions on which medication is best } \\
\text { for you.' Possibility to enroll in } \\
\text { ancestors might have come from and } \\
\text { about relationships between families.' } \\
\text { diagnosis could qualify a person to } \\
\text { enrol in research studies, which may } \\
\text { lead to new treatments.' Insight into } \\
\text { ancestry: 'DNA-testing can provide } \\
\text { insorson's ancestry. } \\
\text { frion of DNA variations can }\end{array}$ & $\begin{array}{l}\text { Psychological: 'The greatest concern pertains } \\
\text { to the way a DNA test result might change a } \\
\text { person's life. The decision to have DNA testing } \\
\text { can be stressful. You may have emotional } \\
\text { reactions to learning that you do- or do not- } \\
\text { carry a gene change for a certain condition.' } \\
\text { Implications for family members: 'Sometimes } \\
\text { a test result may not only affect you, but also } \\
\text { your family relationships. A person who decides } \\
\text { to have DNA testing needs to consider whether } \\
\text { to tell other family members. Sometimes the } \\
\text { result for one family member can disclose } \\
\text { information about the genetic makeup of other } \\
\text { relatives, even if they have not been tested.' } \\
\text { Discrimination risks: 'In some countries a DNA } \\
\text { test result may also affect a person's ability to } \\
\text { obtain health, life, disability or long-term care } \\
\text { insurance. It could also affect the ability to } \\
\text { obtain or keep a job.' }\end{array}$ \\
\hline
\end{tabular}

This article is protected by copyright. All rights reserved. 


\begin{tabular}{|c|c|c|}
\hline Company & Benefits & Risks \\
\hline $\begin{array}{c}\text { Gene By } \\
\text { Gene }\end{array}$ & $\begin{array}{l}\text { Knowledge about disease risks and } \\
\text { predispositions, information about } \\
\text { carrier status, only for 'Clinical Genetic } \\
\text { Testing': 'The purpose of clinical } \\
\text { genetic testing is to evaluate the } \\
\text { presence of the predisposition to } \\
\text { genetic diseases, to assess the risk for } \\
\text { developing a genetic disease, or to } \\
\text { determine the carrier status of a known } \\
\text { disease-causing mutation.' }\end{array}$ & $\begin{array}{l}\text { Psychological, discrimination risks for 'Clinical } \\
\text { Genetic Testing' only: 'Gene By Gene, LTD. is } \\
\text { not responsible for legal, material, social, } \\
\text { psychological, or moral consequences related to } \\
\text { the results of genetic testing. ' Only for } \\
\text { 'Research and Consumer Testing': 'The } \\
\text { customer is aware that some of the information } \\
\text { received may be unexpected, and the customer } \\
\text { takes responsibility for all possible } \\
\text { consequences resulting from test data and } \\
\text { sharing this data.' }\end{array}$ \\
\hline
\end{tabular}

This article is protected by copyright. All rights reserved. 


\begin{tabular}{|c|c|c|}
\hline Inneova & $\begin{array}{l}\text { Knowledge about disease risks and } \\
\text { predispositions: 'I understand the } \\
\text { basic concept of predictive genetics } \\
\text { testing and how it may result in the } \\
\text { discovery of genetic predispositions } \\
\text { that could indicate an increased or } \\
\text { decreased risk of developing certain } \\
\text { medical conditions and diseases. I } \\
\text { realize the possible far-reaching } \\
\text { implications of the information } \\
\text { obtained through predictive genetics } \\
\text { testing in affecting my life choices as } \\
\text { well as those of my relatives, children, } \\
\text { and unborn children. (...) ICL is obliged } \\
\text { to (...) provide me with predictive } \\
\text { genetics test results, as well as an } \\
\text { indicative, preliminary personalized } \\
\text { report for each test performed based } \\
\text { on statistical genetic research into the } \\
\text { behaviour and interaction of genes } \\
\text { with factors such as aging, nutritional } \\
\text { and lifestyle choices, as well as various } \\
\text { diseases and how they could affect my } \\
\text { health and well being.' }\end{array}$ & $\begin{array}{l}\text { Medical, psychological risks, implications for } \\
\text { family members, discrimination risks: 'I } \\
\text { realize the possible far-reaching implications of } \\
\text { the information obtained through predictive } \\
\text { genetics testing in affecting my life choices as } \\
\text { well as those of my relatives, children, and } \\
\text { unborn children. (...) I agree that ICL (together } \\
\text { with its medical, scientific, and other service } \\
\text { partners, subsidiaries and related business } \\
\text { entities, legal advisors, agents, or appointees) } \\
\text { assumes no liability for any stress, strain, } \\
\text { hardship, adverse medical condition, financial } \\
\text { Ioss, or other circumstances that I may suffer as } \\
\text { a result of the receipt or reference to any } \\
\text { predictive genetics test results and/or } \\
\text { interpretations thereof supplied to me by ICL.' }\end{array}$ \\
\hline
\end{tabular}

This article is protected by copyright. All rights reserved. 
Table 4 Information regarding the management of incidental findings resulting from WGS included in the studied sections of the companies' websites. The websites were accessed on 25 October 2014.

\begin{tabular}{|c|c|c|c|c|}
\hline \multicolumn{2}{|c|}{ Company, type of test } & Incidental findings & $\begin{array}{l}\text { Categorization of the } \\
\text { genetic information }\end{array}$ & $\begin{array}{l}\text { Right not to } \\
\text { know }\end{array}$ \\
\hline \multirow{3}{*}{ Illumina } & $\begin{array}{l}\text { TruGenome } \\
\text { Undiagnosed } \\
\text { Disease Test }\end{array}$ & $\begin{array}{l}\text { Provides 'incidental } \\
\text { findings' report of } \\
\text { variants located in the } \\
\text { genes recommended by } \\
\text { ACMG }\end{array}$ & No information & No information \\
\hline & $\begin{array}{l}\text { TruGenome } \\
\text { Predisposition } \\
\text { Screen }\end{array}$ & No information & $\begin{array}{l}\text { Yes, categories: childhood } \\
\text { onset and adult onset; } \\
\text { subcategories: medically } \\
\text { actionable, not medically } \\
\text { actionable, cancer, } \\
\text { neurologic conditions }\end{array}$ & $\begin{array}{l}\text { Yes, option for } \\
\text { excluding some } \\
\text { of the categories } \\
\text { from the test } \\
\text { results }\end{array}$ \\
\hline & $\begin{array}{c}\text { TruGenome } \\
\text { Technical } \\
\text { Sequence Data }\end{array}$ & Not applicable & Not applicable & Not applicable \\
\hline \multicolumn{2}{|r|}{ Gentle } & No information & No information & Yes \\
\hline \multicolumn{2}{|c|}{ Gene By Gene } & No information & No information & No information \\
\hline \multicolumn{2}{|r|}{ Inneova } & No information & No information & No information \\
\hline
\end{tabular}

This article is protected by copyright. All rights reserved. 